\title{
BACE1 inhibitory activity of fungal endophytic extracts from Malaysian medicinal plants
}

\author{
Azzeme Harun', Richard Muhammad Johari James², Siong Meng Lim, Abu Bakar Abdul Majeed², \\ Anthony $L J$ Cole $^{3}$ and Kalavathy Ramasamy ${ }^{1^{*}}$
}

\begin{abstract}
Background: BACE1 was found to be the major $\beta$-secretase in neurons and its appearance and activity were found to be elevated in the brains of AD patients. Fungal endophytic extracts for BACE1 inhibitory activity and cytotoxicity against PC-12 (a rat pheochromocytoma with neuronal properties) and WRL68 (a non-tumorigenic human hepatic) were investigated.
\end{abstract}

Methods: Endophytes were isolated from plants collected from Kuala Pilah, Negeri Sembilan and the National Park, Pahang and the extracts were tested for BACE1 inhibition. For investigation of biological activity, the pure endophytic cultures were cultivated for 14 days on PDA plates at $28^{\circ} \mathrm{C}$ and underwent semipolar extraction with ethyl acetate.

Results: Of 212 endophytic extracts $(1000 \mathrm{\mu g} / \mathrm{ml}), 29$ exhibited more than 90\% inhibition of BACE1 in the preliminary screening. Four extracts from isolates HAB16R13, HAB16R14, HAB16R18 and HAB8R24 identified as Cytospora rhizophorae were the most active with $I_{50(B A C E 1)}$ values of less than $3.0 \mu \mathrm{g} / \mathrm{ml}$. The most active extract HAB16R13 was shown to non-competitively inhibit BACE1 with $K_{\mathrm{i}}$ value of $10.0 \mu \mathrm{g} / \mathrm{ml}$. HAB16R13 was considered non-potent against PC-12 and WRL68 (IC $\mathrm{C}_{50(\mathrm{CT})}$ of 60.0 and $40.0 \mu \mathrm{g} / \mathrm{ml}$, respectively).

Conclusions: This first report on endophytic fungal extract with good BACE1 inhibitory activity demonstrates that more extensive study is required to uncover the potential of endophytes.

\section{Background}

Alzheimer's disease (AD) is the most common cause of dementia in elderly people, and the fourth most common cause of death in developed countries [1]. It is estimated that about 18 million people worldwide are currently affected by this disease and this figure is projected to double by 2025 with an ageing population [2].

Patients diagnosed with AD suffer memory loss, language deterioration, poor judgment and impaired visuospatial capability [3]. At present, there is no cure for AD. Medication for AD only helps slow down progression of the disease so as to improve patients' quality of life. Histopathologically, AD is characterized by the formation of neurofibrillary tangles (NFT) from phosphorylated tau protein in the neurons and the

\footnotetext{
* Correspondence: kalav922@salam.uitm.edu.my

${ }^{1}$ Collaborative Drug Discovery Research (CDDR) Group, Faculty of Pharmacy, Universiti Teknologi MARA (UiTM) Puncak Alam Campus, 42300 Bandar

Puncak Alam, Selangor Darul Ehsan, Malaysia

Full list of author information is available at the end of the article
}

deposition of $\beta$-amyloid ( $A \beta)$ plaque in the parenchyma of the amygdale, hippocampus and neocortex of the brain [4]. The major component of amyloid plaque is the $\beta$-amyloid protein $(A \beta)$, a $39-43$ amino acid peptide composed of a portion of the transmembrane domain and the extracellular domain of the amyloid precursor protein (APP) [5]. A $\beta$ is produced by a sequential cleavage of APP at the amino terminal end by $\beta$-secretase followed by $\gamma$-secretase at the carboxyl terminal end [6]. $\beta$-secretase has been identified as an aspartic protease, $\beta$-site amyloid precursor protein cleaving enzyme 1 (BACE1), also called Asp 2 (for novel aspartic protease 2) and memapsin 2 (for membrane aspartic protease/ pepsin 2). It is currently the most attractive target for the inhibition of amyloid production since it is the key enzyme that initiates the formation of $A \beta$ [7]. Furthermore, BACE1 was found to be the major $\beta$-secretase in neurons [8] and its expression and activity were found to be elevated in the brains of $\mathrm{AD}$ patients.

\section{Biomed Central}

() 2011 Harun et al; licensee BioMed Central Ltd. This is an Open Access article distributed under the terms of the Creative Commons Attribution License (http://creativecommons.org/licenses/by/2.0), which permits unrestricted use, distribution, and reproduction in any medium, provided the original work is properly cited. 
$\beta$-secretase inhibitors have potential to be developed as anti-dementia drugs. Nevertheless, all drugs considered for $\mathrm{AD}$ must be able to cross the plasma membrane, and most importantly the blood-brain-barrier [9]. Enzyme inhibitors with therapeutic potential should preferably be smaller than $700 \mathrm{Da}$, making large peptide-based inhibitors not viable as drug candidates [10]. Thus, the secondary metabolites of plants and microbes, which have relatively low-molecular weights and high lipophilicity, may offer possibilities for drugs against AD [10].

Plants serve as a reservoir of microorganisms known as endophytes [11]. These endophytes, mostly fungi and bacteria, live in the intercellular spaces of plant tissues. Endophytes have high diversity and are relatively fast growing on routinely used laboratory media. Many of the endophytes species are able to produce large amount of novel compounds and is predicted to be a major source for new and useful metabolites [12]. To the best of our knowledge, their ability to produce compounds that inhibit $\beta$-secretase have not been previously reported.

\section{Methods \\ Fungi}

Fungal endophytes were obtained from the culture collection of the Collaborative Drug Discovery Research (CDDR) Group, Faculty of Pharmacy, Universiti Teknologi MARA (UiTM), Malaysia. They were previously isolated from medicinal plants from rainforest parks in Malaysia (Kuala Pilah, Negeri Sembilan [13], and the National Park, Pahang [14]). Axenic cultures were maintained on potato dextrose agar (PDA, Oxoid) plates. Extracts of cultures grown for 14 days at $28^{\circ} \mathrm{C}$ on PDA plates were assessed for bioactivity. A total of 212 strains were grown for investigation.

\section{Semipolar extraction of fungal cultures}

Semipolar extraction was as described previously by Ramasamy et al. [13]. Briefly, after 14 days of incubation, 10 plates of each isolate were transferred into a conical flask $(500 \mathrm{ml})$ and homogenized using a homogenizer (Kika Labortechnik, T25). Ethyl acetate $(200 \mathrm{ml})$ was added and left to stir overnight at room temperature. The mixture was filtered through Whatman No.1 filter paper, after which sodium sulphate was added to remove the aqueous layer within the mixture. The mixture was then transferred to a round bottom flask (500 $\mathrm{ml}$ ) and dried using a rotary evaporator (Buchi, R-215). The resultant extract was dissolved in $1 \mathrm{ml}$ dimethylsulfoxide (DMSO) (Sigma) and stored at $-20^{\circ} \mathrm{C}$ until use.

\section{BACE1 inhibitory activity}

Crude endophytic extracts $(1000 \mu \mathrm{g} / \mathrm{ml})$ were assayed for BACE1 inhibition using a fluorescence resonance energy transfer (FRET) assay (Pan Vera Co.), that uses baculovirus-expressed BACE-1 and a specific substrate (Rh-EVNLDAEFK-quencher) based on the Swedish mutation of the amyloid precursor protein (APP). This peptidic substrate becomes highly fluorescent upon enzymatic cleavage. A mixture of $10 \mu \mathrm{l}$ of BACE1 substrate (Rh-EVNLDAEFK quencher, in $50 \mathrm{nmol} / \mathrm{l}$ ammonium bicarbonate), $10 \mu \mathrm{l}$ of test compound, and $10 \mu \mathrm{l}$ of BACE1 ( $\beta$-secretase) enzyme [(50 mM Tris (pH7.5), $10 \%$ glycerol) $(1.0 \mathrm{U} / \mathrm{ml})]$ were incubated for $60 \mathrm{~min}$ at room temperature and protected from light. Then $10 \mu \mathrm{l}$ of BACE1 stop buffer $(2.5 \mathrm{~mol} / \mathrm{l}$ sodium acetate) was added to the mixture. Fluorescence was read using a multiwell spectrofluorometer (infiniteM200, TECAN) under excitation at $545 \mathrm{~nm}$ and the emitted light at 585 $\mathrm{nm}$. Percentage inhibition of the enzyme was then calculated. In the preliminary screening all 212 endophytic extracts were tested for BACE1 inhibition using a single concentration of $1000 \mu \mathrm{g} / \mathrm{ml}$. Active extracts showing $>90 \%$ BACE1 inhibition in preliminary screening were then reexamined at a concentration ranging from 0.1 $\mu \mathrm{g} / \mathrm{ml}$ to $1000 \mu \mathrm{g} / \mathrm{ml}$ to determine the $\mathrm{IC}_{50 \text { (BACE } 1 \text { ) }}$ values. The $\mathrm{IC}_{50}$ (BACE1) value is defined as the concentration of BACE1 inhibitor that is required to inhibit $50 \%$ of BACE1 activity.

\section{Determination of the inhibition pattern on BACE1}

To investigate the BACE1 inhibition pattern, the most active endophytic extract (HAB16R13) was added to each reaction mixture. The BACE1 inhibitory activity was measured at different concentrations of substrate. The inhibition constant $\left(K_{\mathrm{i}}\right)$ of $\beta$-secretase inhibitor was then calculated using Dixon plots. The reaction velocity is measured at a fixed concentration of substrate but with different extract concentrations (from $0.1 \mu \mathrm{g} / \mathrm{ml}$ to $1000 \mu \mathrm{g} / \mathrm{ml}$ ). The 1/V0 (RFU/min) against inhibitor concentration was plotted and the kinetics of BACE1 in the presence of the inhibitor determined.

\section{Cytotoxicity}

PC-12 (ATCC CRL-1721), a rat pheochromocytoma was maintained in DMEM high glucose (PAA Laboratories) supplemented with $10 \%$ horse serum, $5 \%$ heat-deactivated foetal bovine serum (FBS) and 1\% penicillin/streptomycin. PC-12 has neuronal properties and expression of BACE1 is readily detectable in neuronal cells [15-17]. WRL68 (ATCC CL-48), a non-tumorigenic fetal hepatic cell was maintained in RPMI 1640 (Sigma) supplemented with $10 \%$ heat-deactivated foetal bovine serum (FBS) (PAA Laboratories) and $1 \%$ penicillin/streptomycin (PAA Laboratories). Cells of about $80-85 \%$ confluence were harvested and plated onto 96-flat bottom well plates for experimental use. The culture was maintained in a humidified incubator at $37^{\circ} \mathrm{C}$ in an atmosphere of $5 \% \mathrm{CO}_{2}$. 
The extract showing the greatest BACE1 inhibitory activity HAB16R13 was then tested (at various concentrations from $0.1 \mu \mathrm{g} / \mathrm{ml}-1000 \mu \mathrm{g} / \mathrm{ml}$ ) for cytotoxicity against PC-12 and WRL68 using the MTT assay [18]. Plates were read using an Elisa plate reader (Perkin Elmer) at $520 \mathrm{~nm}$. Data generated was used to plot a dose-response curve of which the concentration of extract required to kill $50 \%$ of the cell population $\left(\mathrm{IC}_{50}\right.$ (CT) was determined.

\section{DNA extraction, PCR amplication and sequencing}

The active isolates (HAB16R13, HAB16R14, HAB16R18 and HAB8R24) were identified. using molecular methods. Fungal DNA extraction was carried out using MasterPure Yeast DNA Purification Kit (Epicentre, USA). $18 \mathrm{~S}$ ribosome DNA sequence was isolated by PCR using Internal Transcribed Spacer ITS-1 primer (TCCGTAGGTGAACCTGCGG) and ITS-4 (5'TCCTCCGCTTATTGATATGC-3'). The amplification was performed in a total reaction volume of $100 \mu \mathrm{l}$ containing $50 \mu \mathrm{l}$ of GoTaq Green Master Mix (Promega, USA), $4 \mu \mathrm{l}$ of each of the primer, $6 \mu \mathrm{l}$ of DNA template and $36 \mu \mathrm{l}$ of nuclease free water using Applied Biosystems GeneAmp PCR System 9600 (Biorad, USA). PCR condition consisted of an initial denaturing step of 1 min at $94^{\circ} \mathrm{C}$ followed by 40 cycles of $95^{\circ} \mathrm{C}$ for $30 \mathrm{~s}$, annealing at $50^{\circ} \mathrm{C}$ for $1 \mathrm{~min}$ and $72^{\circ} \mathrm{C}$ for $30 \mathrm{~s}$. The reaction was completed with final extension at $72^{\circ} \mathrm{C}$ for $7 \mathrm{~min}$ and at $25^{\circ} \mathrm{C}$ for $30 \mathrm{~s}$. The amplified PCR product was separated by electrophoresis in $1.5 \%(\mathrm{w} / \mathrm{v})$ agarose gel at $90 \mathrm{~V}$ for $40 \mathrm{~min}$ in $1 \times$ Tris-acetate-EDTA (TAE) buffer, stained with ethidium bromide and visualized under UV light and photographed. A 100-bp size marker (Promega, USA) was used as reference. The amplified PCR product was purified using Wizard ${ }^{\circledR}$ SV Gel and PCR Clean-Up System (Promega, USA) and subsequently sent for sequencing. The analysis and comparison of the sequences were performed with nucleotide blast of GenBank (http://www.ncbi.nlm.nih.gov). The sequences were deposited in GenBank.

\section{Phylogenetic analysis}

The ITS sequences were aligned to each other as well as the sequences retrieved from the NCBI databases, using multiple sequence alignment software CLUSTAL W program with default settings [19]. Phylogenetic analyses were performed by the neighbour-joining (NJ) method using Molecular Evolutionary Genetic Analysis 4 (MEGA4) software [20]. Parsimony trees were obtained using the Close-Neighbor-Interchange algorithm with search level 3, in which the initial trees were obtained with ten random addition replicates of the sequences $[21,22]$. All positions containing gaps and missing data were eliminated from the dataset (complete deletion option). Tree stability was evaluated by 1000 parsimony bootstrap replicates [21]. Branches corresponding to partitions reproduced in less than $50 \%$ bootstrap replicates were collapsed. A phylogenetic tree was constructed from distance matrix values by the neighbourjoining (NJ) method using the p-distance parameter model to estimate evolutionary distance. A bootstrap analysis was performed using 1000 resamples of the data. Phomopsis theae isolate NW284w was used as an outgroup.

\section{Statistical analysis}

Differences between the extracts were evaluated using the one-way ANOVA procedure in SPSS version 16.0. When there was a difference, the LSD (least significant different) post hoc test was used to identify pairs that differed significantly. Significance was $P<0.05$ unless otherwise stated.

\section{Results}

\section{BACE1 inhibitory activity}

BACE1 inhibitory activity of 212 endophytic extracts $(1000 \mu \mathrm{g} / \mathrm{ml})$ in preliminary screening found $13.7 \%$ (29) to be very active with $>90 \%$ inhibition of BACE1 activity. A further $13.7 \%$ (29) of the extracts also showed very good activity (80-89.9\% inhibition). 14.2\% (30) and $32.5 \%$ (69) of the extracts displayed $70-79.9 \%$ and $50-$ $69.9 \%$ inhibition, respectively. The remaining $25.9 \%$ (55) exhibited $<50 \%$ inhibition of BACE1 activity. IC $_{50}$ (BACE1) values of 29 of the most active strains are shown in Table 1. Four extracts, HAB16R13, HAB16R18, HAB16R14 and HAB8R24 exhibited IC 50 (BACE1) values of less than $3.0 \mu \mathrm{g} / \mathrm{ml}$. HAB16R13 $\left(\mathrm{IC}_{50}\right.$ (BACE1) $=2.15$ $\mu \mathrm{g} / \mathrm{ml})$, showed the best BACE1 inhibitory activity.

\section{Determination of the inhibition pattern on BACE1}

The inhibition pattern displayed by the most active HAB16R13 endophytic extract was then studied. Plots of the initial velocity versus endophytic extract concentrations in the presence of different substrate concentrations gave a family of straight lines. The inhibition pattern of extract HAB16R13 $\left(K_{\mathrm{i}}=10 \mu \mathrm{g} / \mathrm{ml}\right)$ against BACE1 from the Dixon plot (Figure 1) was found to be non-competitive with the substrate at the active site of BACE1. It may bind to either another regulatory site or to the subsite of $\beta$-secretase.

\section{Cytotoxicity}

Extract HAB16R13 when tested against PC-12 and WRL68 showed IC $\mathrm{IO}_{\text {(CT) }}$ values of 60.0 and $40.0 \mu \mathrm{g} / \mathrm{ml}$ respectively (Figure 2), which are considered to be nonpotent. The criterion established by the US NCI is that crude extract with $\mathrm{IC}_{50}$ (CT) value of less than $20 \mu \mathrm{g} / \mathrm{ml}$ is considered to have in vitro cytotoxicity [23]. 
Table 1 BACE1 inhibitory activity (IC 50 (BACE1) of active endophytic extracts

\begin{tabular}{|c|c|}
\hline Strain & $\mathrm{IC}_{50 \text { (BACE1) }}(\mu \mathrm{g} / \mathrm{ml}) \pm \mathrm{SD}$ \\
\hline HAB16R13 & $2.15 \pm 0.49^{a}$ \\
\hline HAB16R18 & $2.40 \pm 0.14^{b}$ \\
\hline HAB16R14 & $2.85 \pm 0.91^{b}$ \\
\hline HAB8R24 & $2.85 \pm 0.07^{b}$ \\
\hline HAB16R12 & $3.10 \pm 0.84^{b}$ \\
\hline HAB6S14 & $5.25 \pm 0.35^{b}$ \\
\hline HAB15R7 & $6.00 \pm 2.12^{b}$ \\
\hline HAB16R15 & $6.15 \pm 2.01^{b}$ \\
\hline KK9R1 & $6.20 \pm 1.69^{b}$ \\
\hline HAB16R11 & $6.45 \pm 0.77^{b}$ \\
\hline HAB6S11 & $7.00 \pm 4.24^{b}$ \\
\hline HAB13S18 & $7.75 \pm 0.35^{b}$ \\
\hline HAB4L5 & $8.50 \pm 3.53^{b}$ \\
\hline HAB6R8 & $9.25 \pm 1.06^{b}$ \\
\hline HAB4L3 & $11.00 \pm 4.42^{b}$ \\
\hline KT36L1 & $11.10 \pm 1.27^{b}$ \\
\hline HAB15R6 & $11.50 \pm 2.12^{b}$ \\
\hline HAB16L32 & $11.50 \pm 0.70^{b}$ \\
\hline KK11S3 & $12.50 \pm 3.53^{b}$ \\
\hline KT39R1 & $16.50 \pm 4.94^{b}$ \\
\hline HAB26S6 & $19.00 \pm 1.41^{b}$ \\
\hline KT44S3 & $25.00 \pm 7.07^{b}$ \\
\hline KT34L2 & $34.00 \pm 7.07^{b}$ \\
\hline HAB8R19 & $40.00 \pm 14.14^{c}$ \\
\hline HAB13L4 & $42.50 \pm 3.53^{c}$ \\
\hline HAB13L2 & $45.00 \pm 7.07^{c}$ \\
\hline HAB12S12 & $55.00 \pm 7.07^{c}$ \\
\hline HAB13S13 & $57.50 \pm 24.74^{c}$ \\
\hline HAB13R29 & $80.00 \pm 28.28^{c}$ \\
\hline
\end{tabular}

${ }^{a-c}$ Means with no common superscript differ significantly $(P<0.05)$.

\section{Molecular identification and phylogenetic analysis}

The ITS of HAB16R13, HAB16R14. HAB16R18 and HAB8R24 were found to be 586-593 bp in length. A BLAST search of the ITS of all four isolates revealed that they were nearly identical to Cytospora rhizophorae (98-99\% similarity). A further phylogenetic analysis based on ITS sequences was conducted to compare the sequences with those in GenBank to determine their relationship and authenticate the identification. There was a total of 481 positions in the final dataset, out of which 37 were parsimony informative (Figure 3). Similar results were obtained using neighbour-joining analyses (results not shown). Most of the clades were supported by bootstraps values (34$96 \%$ bootstrap support). All four isolates were found to be in the same clade with Cytospora rhizophorae strain MUCC302 and Cytospora eucalyptina. Cytospora rhizophorae is from the class Ascomycetes, order Diaporthales and family Valsaceae.

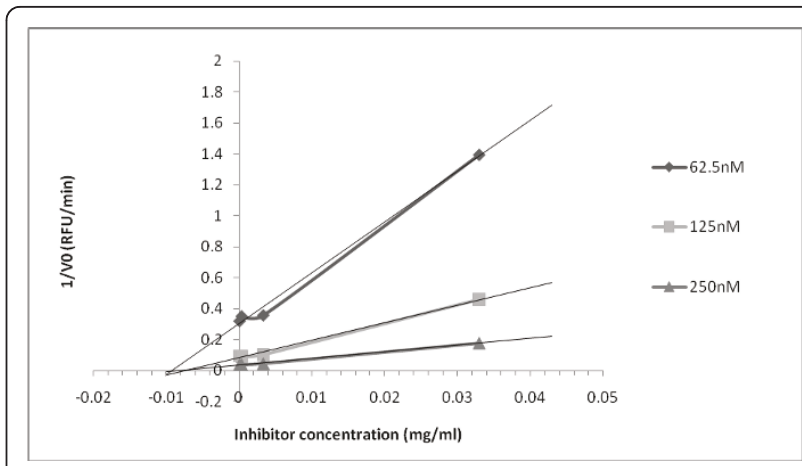

Figure 1 Dixon plot to determine the inhibition constants of HAB16R13 against BACE1 at various substrate concentrations.

\section{Discussion}

Endophytic fungi, HAB16R13, HAB16R14 and HAB16R18 were isolated from the roots of Cinnamomum porrectum while HAB8R24 from Polyalthia glauca. Oil from the root of C. porrectum has been documented to exhibit antimicrobial activity [24] and Polyalthia sp. used as an aphrodisiac, anti-parasite, anti-rheumatic and as an anti-inflammatory agent [25]. Although the compounds responsible for the BACE1 inhibitory activity were not identified in the present study, Cytospora sp. has been reported to produce cytosporacin [26], grahamimycin A [27], cytoskyrin A [28] and cytosporone E [29]. These compounds have been reported to exhibit antimicrobial activity [27-30]. Interestingly, cytosporic acid was found to inhibit a critical enzyme involved in the replication of HIV with an $\mathrm{IC}_{50}$ of $20 \mu \mathrm{M}$ [28]. The pure compound cytoskyrin A, displayed poor cytotoxicity against some tumor cell lines $\left(\mathrm{IC}_{50}>5 \mu \mathrm{g} / \mathrm{ml}\right)$ in vitro [29]. Grahamimycin A also did not induce any toxic symptoms in adult mice [27].

Many groups have focused on high-throughput screening of chemical libraries for BACE1 inhibitors

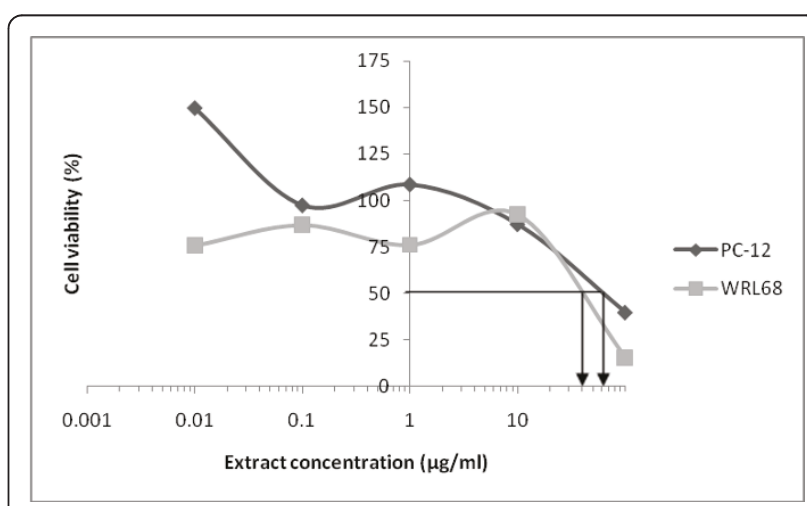

Figure 2 Cytotoxic effects of HAB16R13 against PC-12 and WRL68 cell lines. Each point is expressed as the mean of three independent experiments. 


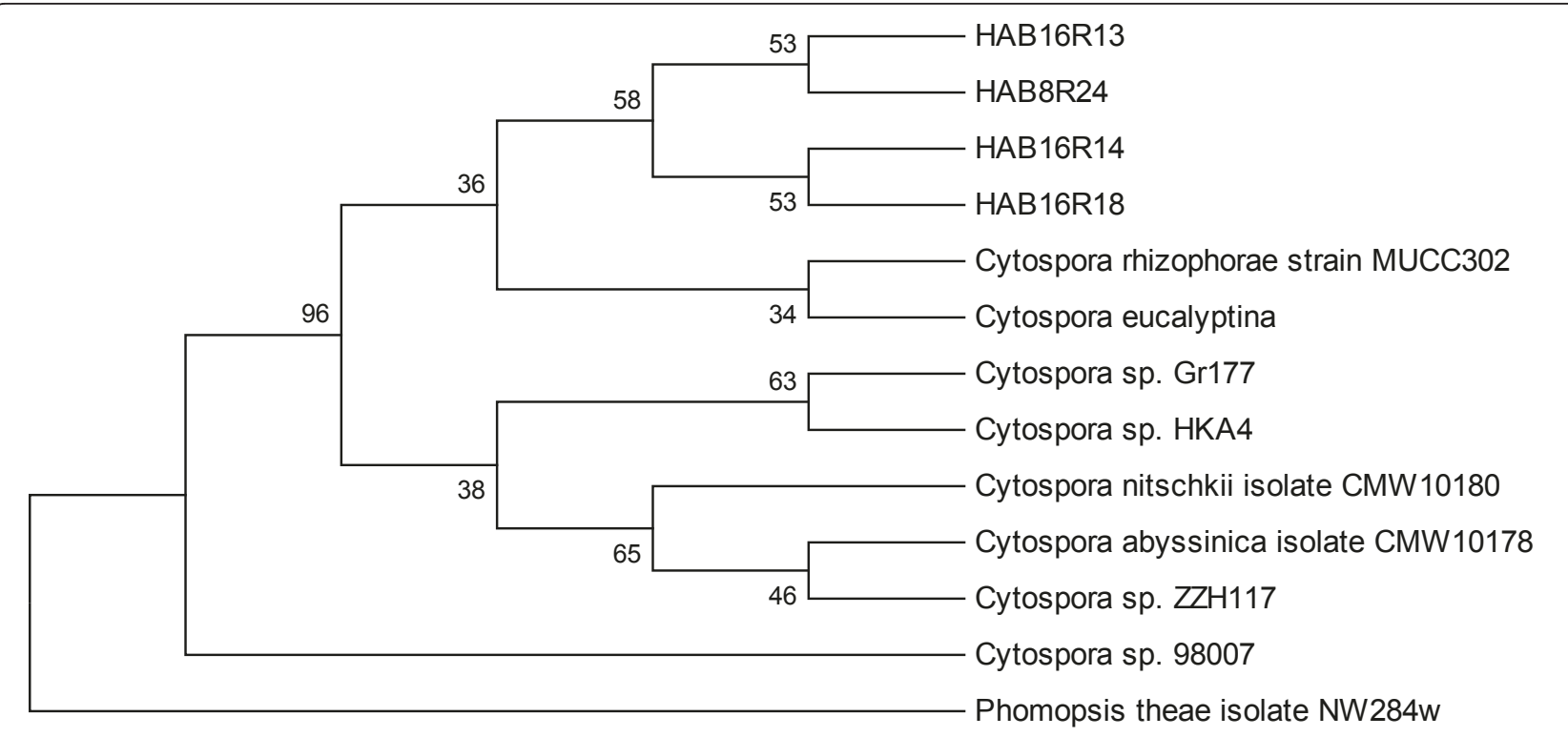

Figure 3 Tree obtained by heuristic search in phylogenetic analysis of the ITS regions of the rDNA of, HAB16R13, HAB16R14, HAB16R18 and HAB8R24 as well as reference isolates. Phomopsis theae isolate NW284w is used as outgroup. Bootstrap confidence level based on 1000 resamples is given on the appropriate branches.

but discovery of naturally occurring BACE1 inhibitors have been limited. Thus far only one BACE1 inhibitor drug candidate (CTS-21166) has completed the Phase 1 clinical trial [31]. Several hydroxyl-containing compounds (hydroxyethylene and hydroxyethylamine) have been reported as BACE1 inhibitors [32,33]. Chitosan derivatives from crab shell and latifolin from Dalbergia sissoo have shown weak BACE1 inhibition [34,35]. Catechins from green tea [13], ellagic acid and punicalagin from pomegranate [36], hispidin from mycelial cultures of Phellinus linteus [37] and several compounds isolated from Sanguisorbae radix [38] have all been studied as BACE1 inhibitors. In order to have therapeutic potential, however efficacious penetration of the blood-brain barrier requires the molecular weights of inhibitors to be under $700 \mathrm{Da}$ making large peptide-based inhibitors unsuitable as drug candidates. Thus, plants and microbial metabolites that have relatively low molecular weights and lipophilicity may be suitable as drug candidates for BACE1 inhibition [39].

Based on the prevailing view on the fundamental role of $A \beta$ in the pathogenesis of $A D$, there seems to be good reason to expect that $\beta$-secretase inhibitor drugs may alter the course of the disease [31]. This first report of a fungal endophyte producing a BACE1 inhibitor would indicate they warrant further investigation.

\section{Conclusion}

In conclusion, this preliminary screening of fungal endophytic extracts revealed their potential as a source of BACE1 inhibitors which could have a role in the development of drugs for treatment of neurodegenerative diseases.

\section{Acknowledgements}

This work was partially funded through grants under the project number 0201-01-540104 (e-Science) and 100-IRDC/BIOTEK 16/6/2 B(1/2008) by the

Ministry of Science Technology and Innovation, Malaysia. Pharmacology and Toxicology Research Laboratory, Universiti Teknologi MARA (UiTM), Malaysia is thanked for the WRL68 (ATCC CL-48) cell line provided.

\section{Author details}

'Collaborative Drug Discovery Research (CDDR) Group, Faculty of Pharmacy, Universiti Teknologi MARA (UiTM) Puncak Alam Campus, 42300 Bandar Puncak Alam, Selangor Darul Ehsan, Malaysia. ${ }^{2}$ Brain Research Laboratory, Faculty of Pharmacy, Universiti Teknologi MARA (UiTM) Puncak Alam Campus, 42300 Bandar Puncak Alam, Selangor Darul Ehsan, Malaysia. ${ }^{3}$ School of Biological Sciences, University of Canterbury, Private Bag 4800, Christchurch, New Zealand.

\section{Authors' contributions}

KR was the principal investigator who participated in the designing of the study and writing of the manuscript. AH participated in overall conduction of experiments and writing the manuscript. RMJJ, LSM and ALJC participated in the planning of the study and writing the manuscript. ABAM participated in the planning of the study. All authors have read and approve the final manuscript.

\section{Competing interests}

The authors declare that they have no competing interests.

Received: 9 February 2011 Accepted: 24 September 2011 Published: 24 September 2011

\section{References}

1. Yates D, McLoughlin DM: The molecular pathology of Alzheimer's disease. Psychiat 2007, 7:1-5.

2. Vas CJ, Rajkumar S, Tanyakitpisal P, Chandra V: Alzheimer's disease: of emerging importance. Reg Health Forum 2002, 6:39-48. 
3. Darvesh S, Walsh R, Kumar R, Caines A, Roberts S, Magee D, Rockwood K, Martin E: Inhibition of human cholinesterases by drugs used to treat Alzheimer's disease. Alz Dis Assoc Dis 2003, 17:117-126.

4. Sisodia SS, Price DL: Role of the $\beta$-amyloid protein in Alzheimer's disease. FASEB J 1995, 9:366-370.

5. Citron $\mathrm{M}: \beta$-secretase as a target for the treatment of Alzheimer's disease. J Neurosci Res 2002, 70:373-379.

6. Hardy J, Allsop D: Amyloid deposition as the central event in the etiology of Alzheimer's disease. Trends Pharmacol 1991, 12:383-388.

7. Vassar R: $\beta$-secretase (BACE) as a drug target for Alzheimer's disease. Adv Drug Deliver Rev 2002, 54:1589-1602.

8. Sinha S, Anderson JP, Barbour R, Basi GS, Caccavello R, Davis D, Doan M, Dovey HF, Frigon N, Hong J, Jacobson-Croak K, Jewett N, Keim P, Knops J, Lieberburg I, Power M, Tan H, Tatsuno G, Tung J, Schenk D, Seubert P, Suomensaari SM, Wang S, Walker D, Zhao J, McConlogue L, John V: Purification and cloning of amyloid precursor protein $\beta$-secretase from human brain. Nature 1999, 402:537-540.

9. Dewachter I, Van Leuven F: Secretases as targets for the treatment of Alzheimer's disease: the prospects. Lancet Neurol 2002, 1:409-416.

10. Jeon SY, Bae K, Seong YH, Song KS: Green tea catechins as a BACE1 ( $\beta$ secretase) inhibitor. Bioorg Med Chem Lett 2003, 13:3905-3908.

11. Bacon CW, White JF, Stone JK: An overview of endophytic microbes: endophytism defined. In Microbial endophytes.. 1 edition. Edited by: Bacon CW, White JF. New York: Marcel Deker, Inc; 2000:3-29.

12. Dreyfuss MM, Chapela IH: Potential of fungi in the discovery of novel, low-molecular weight pharmaceuticals. In The discovery of natural products with therapeutic potential. Edited by: Gullo VP. London, UK: ButterworthHeinemann; 1994:49-80.

13. Ramasamy K, Lim SM, Abu Bakar H, Ismail N, Ismail MS, Ali MF, Weber JFF, Anthony LC: Antimicrobial and cytotoxic activities of Malaysian endophytes. Phytother Res 2010, 24:640-643.

14. Hazalin AMN, Ramasamy K, Lim SM, Abdul Wahab I, Cole ALJ, Majeed ABA: Cytotoxic and antibacterial activities of endophytic fungi isolated from plants at the National Park, Pahang, Malaysia. BMC Comp Alt Med 2009, 9:46.

15. Acquati $F$, Accarino $M$, Nucci $C$, Fumagalli $P$, Jovine $L$, Ottolenghi $S$, Taramelli R: The gene encoding DRAP (BACE2), a glycosylated transmembrane protein of the aspartic protease family, maps to the down critical region. FEBS Lett 2000, 468:59-64.

16. Bennett BD, Babu-Khan S, Loeloff R, Louis JC, Curran E, Citron M, Vassar R: Expression analysis of BACE2 in brain and peripheral tissues. $J$ Biol Chem 2000, 275:20647-20651.

17. Hussain I, Powell DJ, Howlett DR, Chapman GA, Gilmour L, Murdock PR, Tew DG, Meek TD, Chapman C, Schneider K, Ratcliffe SJ, Tattersall D, Testa TT, Southan C, Ryan DM, Simmons DL, Walsh FS, Dingwall C, Christie G: ASP1 (BACE2) cleaves the amyloid precursor protein at the beta-secretase site. Mol Cell Neurosci 2000, 16:609-619.

18. Mosmann T: Rapid colorimetric assay for cellular growth and survival: application to proliferation and cytotoxicity assay. J Immunol Methods 1983, 65:55-63.

19. Thompson JD, Higgins DG, Gibson TJ: CLUSTAL W improving the sensitivity of progressive multiple sequence alignment through sequence weighting, position-specific gap penalties and weight matrix choice. Nucleic Acids Res 1994, 22:4673-4680

20. Tamura K, Dudley J, Nei M, Kumar S: MEGA4: Molecular Evolutionary Genetics Analysis (MEGA) software version 4.0. Mol Biol Evol 2007, 24:1596-1599[http://www.kumarlab.net/publications].

21. Felsenstein J: Confidence limits on phylogenies: an approach using the bootstrap. Evolution 1985, 39:783-791.

22. Nei M, Kumar S: Molecular evolution and phylogenetics. Oxford University Press, New York, Inci...1 12000

23. Boik J: Cancer at cellular level: cytosine methylation and DNA: a note on cancer prevention. In Natural compounds in cancer therapy. Edited by: Farnell S. Minnesota: Oregon Medical Press; 2001:25.

24. Phongpaichit $\mathrm{S}$, Kummee $\mathrm{S}$, Nilrat $\mathrm{L}$, Itarat $\mathrm{A}$ : Antimicrobial activity of oil from the root of Cinnamomum porrectum. Songklanakarin. J Sci Technol 2006, 29:11-16.

25. Cousins D, Huffman MA: Medicinal properties in the diet of gorillas: an ethno- pharmacological evaluation. Afr Study Monogr 2002, 23:65-89.

26. He H, Janso JE, Williamson RT, Yang HY, Carter GT: Cytosporacin, a highly unsaturated polyketide: application of the ACCORD-ADEQUATE experiment to the structural determination of natural products. $J$ Org Chem 2003, 68:6079-6082.

27. Gurusiddaiah S, Ronald RC: Grahamimycins: Antibiotics from Cytospora sp. Ehrenb. W.F.P.L 13A. Antimicrob Agents 1981, 19:153-165.

28. Singh MP, Janso JE, Brady SF: Cytoskyrins and cytosporones produced by Cytospora sp. CR200: taxonomy, fermentation and biological activities. Mar Drugs 2007, 5:71-84.

29. Hall JD, Duncan-Gould NW, Siddiqi NA, Kelly JN, Hoeferlin LA, Morrison SJ, Wyatt JK: Cytosporone E: racemic synthesis and preliminary antibacterial testing. Bioorgan Med Chem 2005, 13:1409-1413.

30. Jayasuriya H, Guan Z, Polishook JD, Dombrowski AW, Felock PJ, Hazuda DJ, Singh SB: Isolation, structure, and HIV-1 integrase inhibitory activity of cytosporic acid, a fungal metabolite produced by a Cytospora sp. J Nat Prod 2003, 66:551-553.

31. Gosh AK, Gemma S, Tang J: $\beta$-secretase as a therapeutic target for Alzheimer's disease. Neurotherapeutics 2008, 5:399-408.

32. Cumming JN, Iserloh U, Kennedy ME: Design and development of BACE1 inhibitors. Curr Opin Drug Discovery Devrl 2004, 7:536-56.

33. Stachel SJ, Coburn CA, Steele TG, Jones KG, Loutzenhiser EF, Gregro AR, Rajapakse HA, Lai M, Lai MT, Crouthamel MC, Xu M, Tugusheva K, Lineberger JE, Pietrak BL, Espeseth AS, Shi XP, Chen-Dodson E, Holloway MK, Munshi S, Simon AJ, Kuo L, Vacca JP: Structure-based design of potent and selective cellpermeable inhibitors of human $\beta$-secretase (BACE-1). J Med Chem Lett 2004, 47:6447-50.

34. Ramakrishna NVS, Kumar EKSV, Kulkarn AS, Jain AK, Bhat RG, Parkh S: Screening of natural products for new leads as inhibitors of $\beta$-amyloid production: latifolin from Dalbergia sissoo. Indian J Chem 2001, 40:539-40.

35. Je JY, Kim SK: Water-soluble chitosan derivatives as a BACE1 inhibitor. Bioorg Med Chem Lett 2005, 13:6551-5.

36. Kwak HM, Jeon SY, Sohng BH, Kim JG, Lee JM, Lee KB, Jeong HH, Hur JM, Kang YH, Song KS: $\beta$-secretase (BACE1) inhibitors from Pomegranate (Punica granatum) husk. Arch Pharm Res 2005, 28:1328-32.

37. Park $I H$, Jeon $S Y$, Lee HJ, Kim SI, Song KS: A $\beta$-secretase (BACE1) inhibitor hispidin from the mycelial cultures of Phellinus linteus. Planta Med 2004, 70:143-6.

38. Lee HJ, Seong YH, Bae KH, Kwon SH, Kwak HM, Nho SK, Kim KA, Hur JM, Lee KB, Kang YH, Song KS: Beta-secretase (BACE1) inhibitors from Sanguisorbae radix. Arch Pharm Res 2005, 28:799-803.

39. Lee DH, Lee DH, Lee JS: Characterization of a new antidementia $\beta$ secretase inhibitory peptide from Saccharomyces cerevisiae. Enzyme Microb Tech 2007, 42:83-88.

\section{Pre-publication history}

The pre-publication history for this paper can be accessed here: http://www.biomedcentral.com/1472-6882/11/79/prepub

doi:10.1186/1472-6882-11-79

Cite this article as: Harun et al: BACE1 inhibitory activity of fungal endophytic extracts from Malaysian medicinal plants. BMC Complementary and Alternative Medicine 2011 11:79.

\section{Submit your next manuscript to BioMed Central and take full advantage of:}

- Convenient online submission

- Thorough peer review

- No space constraints or color figure charges

- Immediate publication on acceptance

- Inclusion in PubMed, CAS, Scopus and Google Scholar

- Research which is freely available for redistribution

Submit your manuscript at www.biomedcentral.com/submit
C Biomed Central 